SHS Web of Conferences 10, 00052 (2014)

DOI: $10.1051 /$ shsconf $/ 20141000052$

C Owned by the authors, published by EDP Sciences, 2014

\title{
The possibilities and limitation of transcultural biography work: Lithuanian case
}

\author{
I. Zemaitaityte, S. Mikulioniene, and L. Dromantiene \\ Mykolas Romeris University, Lithuania
}

\begin{abstract}
Lithuania, as well as other contemporary societies, is undergoing the times full of new technological, political, economic, social and scientific changes. In the changing society, adult education has helps a person to develop his and her cultural interests, creative powers, skills and acquire theoretical knowledge necessary for person's professional activity, enables a person to upgrade his or her current qualification and helps to become an active citizen of a democratic society (Zemaitaityte, 2007). This paper seeks to discuss Trancultural Biography Work (TBW) as an adult educative approach that is mainly oriented on one's resources and potentials. But it also may help to overcome hindering patterns of thinking, feeling and acting. Through Biography Work, people explore how they handled difficult situations in one's life: How did the person manage similar situations in the past? How did other people or other members of person family with whom he/she shared memory manage it? It supports to gain self-awareness as well as courage and the desire to realize one's potentials. "Realize. Transcultural Biography Work for Adult Education" international project, from 2010 to 2012, was dedicated to apply Transcultural Biography Work (TBW) in different counties and contexts with different participants with various needs and backgrounds, explore and implement new techniques of Transcultural Biography Work, assess the effectiveness of TBW techniques, and elaborate further on Transcultural Biography Work approach.
\end{abstract}

\section{Biography work in adult education}

Adult educative Biography Work is an outcome of biographical methodologies shaped in therapeutic contexts since the beginning of $20^{\text {th }}$ century and of biographical research in different fields also since the $1920^{\text {th }}$ and again popular in the spirit of protest movements since the late $1960^{\text {th }}$. (SchweighoferBrauer, Bono \& others, 2012). Biography Work also is rooted in biographical research as developed mainly in ethnological field studies, sociological qualitative research, narrative research and, since the $1990^{\text {th }}$, in educational science. The biographical approach in those scientific directions has been based on the humanistic psychologies idea of humans and theoretically underlined by structuralism and poststructuralism concepts. "Biographicity" (Alheit 1993 in Schweighofer-Brauer, Bono \& others, 2012) is at the same time defined as a result of the modernity - post-modernity historical process and as a means of personal and social empowerment. Therefore, conscious biographical reflection becomes a way of life to cope with the challenges of creating a personal life-course communicating with the social groups a person is linked to; and communicating with developments in globalized communities (Alberici, 2000).

This is an Open Access article distributed under the terms of the Creative Commons Attribution License 4.0, which permits unrestricted use, distribution, and reproduction in any medium, provided the original work is properly cited. 
Biography method is known and applied in Lithuania mostly in sociology as a research method. In 1994 m. Kasatkina researched Russian intelligentsia of the Republic of Lithuania, reviewing the culture of an ethnic group (minority), its historic background, which is important not only for the country's ethnic composition studies but for the understanding of contemporary ethnic relations. In 2003, there came out a collective study "Social memory, commemorations and deleted memory" (Krukauskiene \& others, 2003), it was dedicated to the traumatic experiences of the Soviet period. The book interpreted results of a biographical research. The authors sought to determine circumstances in which the memories were formed or deleted: "What aspects of the traumatic Stalinism's period events are memorised, which are deleted from the individual and collective memories?" (Krukauskiene \& others, 2003: 11). Kraniauskiene (2000) analysed Biography method as one of the trends in sociology methods which encompases not only practical methods of social research but also some fundamental theoretical considerations. Broad theoretical spectrum of the fundamental Biography method provides a belief that this method with one core element - life history, could combine quantitative and qualitative methodology elements and could provide a broader and deeper and more thorough social life analysis (Kraniauskiene, 2000).

Narrative sociology, education science aim at reflecting past or present situations based on descriptions and reflections of contemporary people - asking for their perception and interpretation which influences or even guides present action and attitude. Biographical research in this sense can be understood as collective Biography Work. Biographical research and its outcomes support Biography Work in adult education and other contexts by providing knowledge on the collective historical contexts of learners, clients and by providing narrative methods to explore such issues (Schweighofer-Brauer, Bono \& others, 2012). It contributed to create new patterns to perceive and understand history, historical experience and events. Application of the Biography Work in adult education will allow to look into subjective personal and public sides of life, to foster a more supportive positive behaviour for the individual decision making processes and to create empowering future visions.

\section{Peculiarities of tranculturality in biography work}

Culture is a multilayered term - broadly discussed in different science, for example in cultural anthropology or cultural studies. Culture defines certain capacities and limitations of an individual, shapes one's world outlook, which is a framework for understanding of reality phenomena (Zemaitaitytè, 2012). Culture also promotes society's creativity which finds its outlets in multiple areas and contexts - from arts and crafts to design, research and entrepreneurship. R. Jančaitytė (Jančaitytė \& others, 2009) determines that culture is a sphere defining and shaping individual's mode of existence in society. Culture could be define as the way how people create, organize, express, but also think, verbalize and reflect their living on earth; how they create a common understanding they can share. The cultural meaning are creating with contribution of schemes of interpretation and interaction. These schemes make nucleus of knowledge and connect this "that was earlier" with "that which will be later" (Giddens, 1979). This process is apparent in adult education whenever individuals reflect on the historical and recent context.

The concept of transculturality as described by Welsch (1999) complies with postmodern de/constructivist thinking of cultural studies. Modern cultures are characterized by a variety of different ways of life and lifestyles and they are border crossing. The concept of transculturality refers to the contemporary reality of border crossing identities which are contradicting the old imagination of closed, homogenous national cultures. It also differs to the concepts of interculturality and mulitculturality. The concept of interculturality preserves this opposition because it continues regarding cultures as islands and only suggests moderating some problematic consequences. The supposition of separate culture leads to perceive a communicative incapability and difficult living together of cultures (Welsch, 1999) judges the intercultural concept as not radical but only similar to the concept of multiculturality. 


\section{Int. Conf. SOCIETY. HEALTH. WELFARE.}

The later one also still assumes separate, homogeneous cultures and asks how they can life together in one society/country. It intends to foster tolerance, acceptance, conflict solving. But it does not offer an interpretative horizon to perceive cultural heterogeneity within culturally defined groups, and to understand transgressing and converging cultural forming. Transculturality - individual has the collection of original cultural elements and seek to define and understand similarities which consolidate him/her with other persons. Transcultural thinking and activity doesn't eliminate differences, but expand the possibilities of understanding of each others. Trasculturality invites to understand culture beyond the opposition of own and foreign culture. Internal transculturality further makes it easier to deal with external transculturality - to find attaching points in multifaceted situations respectively environments (Welsch, 1999).

Orienting Biography Work transculturally focuses on identifying and appreciating personal talents and capabilities learned through living in different cultural contexts. Biography Work - especially if carried out interactively in groups - encourages internal transculturality, encourages a web to be weaved with a multitude of colourful fibres connecting own and others relation and memory. Biography Work helps to discover internal cables to attach. It traces the development of inner dogmata on how the world would be, how one would be and how certain others would be hindering the transcultural attachment. Transcultural biographical self-awareness raises individual self-esteem, but at the same time it strengthens the consciousness of human interdependence, of the ongoing mutual influence. It makes aware that the liberty to shape the interdependency grows with its acknowledgement. Living means learning by facing new situations, people, culture-nets, or ages. And learning means transforming oneself (Schweighofer-Brauer, Bono \& others, 2012).

\section{Realize - International project for development of transcultural biography work}

"Realize. Transcultural Biography Work for Adult Education" - project, from 2010 to 2012, was dedicated to apply Transcultural Biography Work (TBW) in different contexts with different participants with various needs and backgrounds, explore and implement new techniques of TBW, assess the effectiveness of TBW techniques, and elaborate further on TBW approach. Exercised in adult education, Transcultural Biography Work encourages learners to find their personal access to learning and to the issues under consideration. It stimulates learning through reflecting life experience. It inspires to create new perspectives through biographical exchange among each other. Realize project has been funded by the European Union Lifelong Learning Programme as a Grundtvig Multilateral Project (No. 510559-LLP-1-2010-1-IT-GRUNDTVIG-GMP). The Realize project partnership consisted of seven partner organisations in five countries: Speha Fresia (coordinate) and Griot from Rome/Italy; the Süleyman Demirel University from Isparta/Turkey; Haus der Begegnung and Centre of Social Scientific Research, Education and Information from Innsbruck/Austria; the Mykolas Romeris University from Vilnius/Lithuania; and as a silent partner in co-operation the Suisse Federation for Adult Learning (SFAL) in Lugano and Labor Transfer SA in Camorina, both from Suisse.

Objectives of the Realize project:

- Elaborating Transcultural Biography Work as a method to facilitate the access to adult education and to be applied within adult education: to stimulate the creation of new life scripts, inspire an ongoing self reflection in the spirit of lifelong learning and to develop transcultural competences as a key qualification through biographical exchange.

- Designing a course moduls on Transcultural Biography Work, an innovative approach to train professionals to support people with migrant background to reflect their biographical selfconstructions, individual resources and barriers to their access to education and learning.

- Adapting the modules for specific situations and target groups in the consortium countries. 


\section{SHS Web of Conferences}

- Qualifying social workers, family assistants, youth workers, labour insertion counsellors with regard to adult educative methods to inspire their clients desire for learning and to create a base for gaining the know how of entering and remaining in learning processes.

Realize project partners shared the wish to contribute with the Transcultural Biography Work to a prospering co-existenzia of men and women, people of different age, abilities, social, religious, cultural; to facilitate the conditions for people to be able to sustain themselves through labour, to contribute to the wellbeing of societies and to enjoy it.

\section{Implementation of transcultural biography work in Lithuanian}

Following the Realize Project partners agreement Transcultural Biography Work seminars were delivered 16-17 September 2011 and 11 November 2011. 15 participants were present in the seminars. There came active social partners of Mykolas Romeris University: Social workers of the Day Centers, students Social Gerontology Master Degree programmes and professionals of the higher education school - education science specialists. The partners have agreed that the seminars should be attended not by direct beneficiaries (e.g. migrants, representatives of social exclusion groups, unemployed), but by social workers education science specialists, future social workers (students), who would be able to apply Transcultural Biography Work method in their further function. There was no special participant selection procedure in Lithuania, since all invitations were met with interest and confirmations of participation followed (Zemaitaityte, Bono \& others, 2012).

It was tested four Transcultural Biography Work methods in Lithuanian seminars: welcoming exercise "My way to the seminar venue"; drawing method; photos stories and memory journey. All methods tested or discussed in the Lithuanian pilot course have been mentioned all participants to be beneficial for their professional practice. Seminars progressed smoothly, the participants shared their experiences and feelings, actively participated in all activities. Since the group united students and teachers, it was a satisfying observation (noted by the participants themselves), that informal atmosphere of the seminars deleted the distance between the students and the teachers, present in a formal environment (Zemaitaityte, Bono \& others, 2012).

At the close of the seminars the participants mentioned their experiences in their reflections, they were nice, interesting, warm, pleasant and surroundings encouraged understanding. Participants stressed that understanding the own biography helps understanding others; the participation in these seminars produces a new perception of the own biography and of the biographies of others.

"I feel elated. I understand that a lot of work, planning, tasks are ahead. But now I want to make a pause and enjoy the moment... When we are together we learn about the others and the surroundings, but we, first of all, learn about ourselves. By learning oneself it is easier to learn about others...

"I understand that self explorations never ends..."

"I feel great. Creative tasks allow us to know each other much better..."

When asked what they learned in these seminars, the participants stressed tolerance and the importance of sharing experience, they said that stories of others bring own stories to the surface which otherwise would have stayed buried - with the help one learns a lot about oneself and other people.

"I learned to tolerate others, since everyone because they are not me are immediately different from me. I learned to listen to another person and make nojudgement, since I understand that a different opinion is not necessarily wrong...."

"I learned to open to virtual strangers and still feel safe. This experience will help to communicate with colleagues, family members and with people whom barely know."...

"Personal growth - how interesting, meaningful and pleasant to share experiences."

Also the participant noted that during the seminars they could pause to reflect on their experiences and in our fast and continually changing period they cannot spare any time for this at all. 
Int. Conf. SOCIETY. HEALTH. WELFARE.

"I discovered important things in my life, I took some rest from running through life..."

"For personal growth I learned to stop, to listen, to accept my positive experiences and to value..."

"It is a method which in my opinion can stop time, can turn one's look into oneself, to know oneself, and at the same time, allows to understand and accept the other person ..."

By analysing features of Transcultural Biography Work application to Lithuanians, seminar participants mentioned that Lithuanians are reticent to open up in a group of new people; the years of transition formed the feeling of rush, therefore often there is no wish to make a pause, it gives one fears to stand out of the group. The participants have also pointed out that these methods should be applied to children since they will be the generation which deals with new misunderstandings and will form the future.

"It is important to notice Lithuanian "coldness", the fear to open up."

"People must be encouraged to stop and to distance from permanent seeking results and permanent activity".

"I think these methods must be applied rather widely, starting with children. They will be the ones who deal with conflicts and misunderstandings, connected to culture differences."

While discussing the difficulties and challenges in applying Transcultural Biography Work training in Lithuania the first thing to mention is that the participants showed a considerable reluctance when asked to draw their learning road. The first reaction of participants in Biography Work training when asked to draw anything led to comments: I cannot draw well, I draw badly, no one will be able to understand anything. Therefore, some time was taken to explain that this exercise did not ask for skills in drawing but, instead, drawing could be used as a method of connecting with one's memories, and not for the sake of demonstration of artistic inclinations. For this reason, in applying visual (drawing) method the participants subsequently were asked to "visualize" their learning road without resorting to the word "draw". In discussion this negative reaction to the word "draw" many participants connected it to the negative school experience, when any drawing which did not match the teacher's instructions received negative evaluation and public criticism in front of the classmates (Zemaitaityte, Bono \& others, 2012).

Another issue in applying Transcultural Biography Work in Lithuania was to convince the participants from the very start of the seminar to relax and take their time in reflection and task performance. Biography Work is a relatively slow process. It needs time and space to make unexpected learning processes and transformation possible. Therefore at the beginning of the seminars, especially more senior participants would cut the reflection time as pointless, wasted and ask for a more dynamic training process. Yet, at the close of the trainings the participants were happy with the pace, reflection time and the value of reflection.

\section{Conclusions}

1. Exercised in adult education, Transcultural Biography Work encourages learners to find their personal access to learning and to the issues under consideration. It stimulates learning through reflecting life experience and inspires to create new perspectives through biographical exchange among each other.

2. The introduction of Transcultural Biography Work into the continuous learning process in Lithuania favours retraining and professional integration paths. All methods tested and discussed in the Lithuanian seminars have been mentioned all participants to be beneficial for their professional practice. Also the participants stressed tolerance and the importance of sharing experience, have also pointed out that these methods should be applied to both adult and children since they will be the generation which deals with new misunderstandings and will form the future. 


\section{SHS Web of Conferences}

3. While discussing the difficulties and challenges in applying Transcultural Biography Work training in Lithuania, seminar participants mentioned that Lithuanians are reticent to open up in a group of new people; also often there is no wish to make a pause, to reflect. Also participants noted the negative reaction to the word "draw" which many participants connected to the negative school experience.

\section{References}

[1] Alberici A. (2000): Educazione in età adulta. Percorsi biografici nella ricerca e nella formazione, Armando, Roma.

[2] Bono M., Cannova E., Campa F., Carbon M., Comi G., Dromantiene L.,Gnaiger A., Gül H., Kaya H. E., Lottin M., Mikulioniene S., Di Nardo F., Raimondi P., Reiter E., SallanGül S., Schroffenegger G., Schweighofer-Brauer A., Schweigkofler M., Zemaitaityte I. (2012) TRANSCULTURAL BIOGRAPHY WORK (TBW) A Handbook. Published by: Realize project partner organisations, represented by the lead partner organisation: Speha Fresia Società Cooperativa, Roma, Italy.

[3] Giddens A. (1979) Central Problems in Social Theory: Action, Structure and Contradiction in Social Analysis. Berkeley: University of California Press.

[4] Jančaitytė R., Valevičienè N., Augutienė R., Prakapas R. (2009) Tarpkultūrinès kompetencijos didinimas bei ivairovès valdymo gebejjimu stiprinimas, Vilnius, Mykolo Romerio universiteto leidykla.

[5] Kraniauskienè S. (2000) Biografinis metodas: dvi teorinès metodologinès kryptys SOCIOLOGIJA. Mintis ir veiksmas. Klaipėdos universitetas, Socialiniụ tyrimụ / sociologijos istorijos centras.3/4: pp. 78-90.

[6] Krukauskienè, E.; Šutinienë, I.; Trinkūnienè, I.; Vosyliūtè, A. (2003) Socialinè atmintis, minèjimai ir užmarštys. Vilnius: Eugrimas.

[7] Welsch W. (1999): Transculturality - the Puzzling Forms of Cultures today, in: Featherstone, Mike/Lash, Scott (eds.): Spaces of Culture: City, Nation, World, London, pp. 194-213 (auch: http://www2.uni-jena.de/welsch/Papers/transcultSociety.html).

[8] Zemaitaitytė I.(2007) Neformalusis suaugusiuju švietimas: plètros tendencijos dabartinejje Europoje, monografija. Vilnius: Mykolo Romerio universiteto leidykla.

[9] Zemaitaitytė I. (2012) Non governmental organizations' initiatives working with the older people/l Intergenerational solidarity and older adults ' education in community : the third conference of the ESREA network on education and learning of older adults, 19-21 September, 2012 : conference papers, Ljubljana : Faculty of Arts at the University of Ljubljana., pp. 272-279. 